\title{
Market valuation of greenhouse gas emissions under a mandatory reporting regime: evidence from the UK
}

\author{
Diogenis Baboukardos \\ Essex Business School \\ University of Essex \\ Wivenhoe Park, Colchester, C04 3SQ, UK \\ Email: d.baboukardos@essex.ac.uk
}

Accepted for publication in

Accounting Forum

on $25^{\text {th }}$ February 2017

Baboukardos D. (2017)

Market valuation of greenhouse gas emissions under a mandatory reporting regime: evidence from the UK. Accounting Forum, Forthcoming. 


\title{
Market valuation of greenhouse gas emissions under a mandatory reporting regime: evidence from the UK
}

\begin{abstract}
This study provides evidence on the potential benefits of mandatory environmental reporting for listed firms' market valuation. It takes advantage of recent regulation that requires all listed firms in the UK to report their annual greenhouse gas (GHG) emissions in their annual reports and shows that the magnitude of the negative association between GHG emissions and the market value of listed firms decreased after the introduction of the reporting regulation. This decline is attributed to regulation forestalling shareholders' negative reflexive reaction towards firms' carbon disclosures, as proposed by the theoretical work of Unerman and O’Dwyer (2007).
\end{abstract}

Keywords: Greenhouse gas emissions; Value relevance; London Stock Exchange; Mandatory disclosures; Reporting regulation

\section{Introduction}

It is widely acknowledged that sustainability reporting plays a pivotal role in the endeavor to establish a new, sustainable economic model worldwide, which will combine desirable financial outcomes with environmental protection, among other outcomes (European Council and Parliament, 2014; IIRC, 2013). Undeniably, the reporting of greenhouse gas ${ }^{1}$ (hereafter GHG) emissions, as a first step toward reduction of GHG emissions (DEFRA, 2010), is of paramount importance to this endeavor. This is evident both from the plethora of international and national initiatives for GHG emissions reporting ${ }^{2}$ and from the ever-growing research on this topic ${ }^{3}$.

What is also evident is that capital markets have been one of the key factors in the development of GHG emissions reporting since investors integrate this information into their investment decision-making (Kauffmann et al, 2012). Indeed, recent studies have shown that there is a significant negative association between the level of a firm's GHG emissions and its market valuation (Chapple et al, 2013; Clarkson et al, 2015; Matsumura et al, 2014), which is attributed to investors using GHG emissions as a proxy for assessing firms' unbooked future environmental liabilities (Clarkson et al, 2004; Hughes, 2000; Matsumura et al, 2014).

Nevertheless, GHG emissions reporting has been — and still is in most jurisdictions and for most firms around the world - voluntary, with recent studies questioning the quality of such

\footnotetext{
${ }^{1}$ In this study, the terms 'greenhouse gas' and 'carbon' are used interchangeably.

2 Examples include the Carbon Disclosure Project, the North American Climate Registry, the Australian National Greenhouse and Energy Reporting Act and the Canadian Greenhouse Gas Emissions Reporting Program, to name a few.

${ }^{3}$ Ascui (2014) finds that the number of published research papers in the broad field of carbon accounting (which includes carbon reporting) tripled in 2009 compared with the previous year, and the number has continued to increase at an average of $66 \%$ per year since then.
} 
voluntary disclosures (Andrew \& Cortese, 2011; Kolk et al, 2008; Stanny \& Ely, 2008; Sullivan \& Gouldson, 2012). Unerman and O'Dwyer (2007) argue that, when a negative environmental externality of firms' activities attracts public attention, shareholders react reflexively by increasing their socially constructed perception about firms' environmental risk. In turn, this increased perception of risk leads to a reduction of shareholders' trust in firms' voluntary disclosures and, consequently, to a decline in shareholders' value. In recent years, carbon emissions have come into the spotlight as possibly the main cause of global warming (Kauffmann et al, 2012; Stern, 2007). Hence, following the rationale of Unerman and O’Dwyer (2007), voluntary carbon emissions reporting may have lost its trustworthiness, and consequently, capital market participants may impose an extra valuation penalty when they value GHG emissions.

Mandatory GHG emissions reporting has been suggested as a means for mitigating the above problem (Kolk et al, 2008; Rankin et al, 2011; Sullivan \& Gouldson, 2012; Unerman \& O’Dwyer, 2007). If this proposition is true, then the negative association between market value and carbon emissions is expected to decline in magnitude after the introduction of a mandatory GHG emissions reporting regulation. Bewley (2005) provides some evidence of a decline in the valuation penalty imposed by investors when they value-booked environmental liabilities accruals after the introduction of reporting regulation. Nevertheless, whether investors value non-financial environmental information and specifically GHG emissions differently in a mandatory reporting context compared with a voluntary reporting regime is an open empirical question (Andrew and Cortese, 2011).

Since GHG emissions reporting has been largely voluntary, previous studies about GHG emissions have focused primarily on voluntary disclosures (Freedman and Park, 2014). This study takes advantage of the recent amendments of the UK Companies Act 2006 (Strategic Report and Directors' Reports) Regulations 2013 (hereafter the 2013 Regulation), which requires all firms listed on the London Stock Exchange (hereafter LSE) to report their annual GHG emissions in their director's report for financial years ending on or after September 30, 2013, and seeks to provide empirical evidence on whether the expected negative association between firms' market valuation and GHG emissions declined in magnitude after the introduction of a mandatory GHG emissions reporting regulation.

The UK is an interesting setting for the empirical examination of this research question because, according to DEFRA (2012), it is the first country whose listed firms are required to include carbon emissions data for their entire organization in their annual reports. Although 
regulations ${ }^{4}$ related to environmental issues were in place before the introduction of the 2013 Regulation and the vast majority of large listed firms on the LSE disclosed their carbon emissions voluntarily before September $2013^{5}$, there are reasons to believe that the introduction of a regulation that requires firms to report their annual GHG emissions should have a significant impact on their market valuation. First, de Villiers and van Staden (2011) provide evidence that investors in the UK prefer mandatory environmental disclosures to voluntary disclosures, especially when these disclosures are provided through firms' annual reports. The increasing quantity of environmental disclosures found in annual reports of UK firms suggests that environmental issues are of growing economic concern (de Aguiar \& Bebbington, 2014). Furthermore, Tauringana and Chithambo (2015) conclude that in the UK setting, only reporting regulations can make firms disclose information that is useful to stakeholders. In addition, according to DEFRA (2013), mandatory reporting of GHG emissions offers the reporting firms the opportunity to signal strong green credentials to the market. Similar views in favor of mandatory GHG emissions reporting have been expressed by public authorities and industry representatives. For instance, Caroline Spelman, the then-Secretary of State for the Environment, said in June 2012 that “...the reporting of greenhouse gas emissions will give them [A/N: the investors] vital information as they decide where to invest their money." (DEFRA, 2012), whereas two months before the introduction of the then-new regulation, David Harris, the Head of the Environmental Social and Governance branch of the FTSE Russell Index, stated the following:

"While the new regulations are not a silver bullet, they will be an improvement for investors in companies on LSE's [A/N: London Stock Exchange's] main market, providing data that may help with their investment decisions. By making reporting compulsory, data availability and quality will improve, as voluntarily reported data can often be unreliable." (Paddison, 2013)

By utilizing a sample of all non-financial firms listed on the LSE for which GHG emissions data are available for the four-year period of 2011-2014 and employing a linear price-level model that associates a firm's share price to GHG emissions, this study provides evidence that

\footnotetext{
4 The Companies Act 2006 requires listed firms to provide a narrative in their annual reports about their environmental issues to the extent that it is necessary for the understanding of firms' performance, but it does not require disclosure of GHG emissions. The Carbon Reduction Commitment 2010 requires firms that use more than 6,000 MWh per year of energy to measure their emissions, but they must report this information to the governmental Environment Agency and not to the public [for further information about previous regulations, see Kauffmann et al (2012) and KPMG et al (2013)].

5 The Carbon Disclosure Project has been publishing reports about the annual carbon emissions of FTSE 350 firms listed on the LSE since 2006. Further information can be found here: https://www.cdp.net/enUS/Results/Pages/All-Investor-Reports.aspx.
} 
first, similar to other jurisdictions around the world, GHG emissions are negatively associated with firms' market value in the LSE for the whole period under examination; second, the magnitude of the negative association between firms' market price and carbon emissions decreased after the introduction of the 2013 Regulation and; third, the magnitude of the negative association between market value and GHG emissions declined only for firms that belong to energy-intensive industries.

This study adopts the theoretical propositions of Unerman and O'Dwyer (2007), who draw from Giddens's reflexive modernity concept (as cited in Unerman \& O'Dwyer, 2007) in terms of the interaction among reflexivity, risk and trust and intends to contribute to the recent academic debate regarding the market valuation implications of GHG emissions (Chapple et al, 2013; Clarkson et al, 2015; Matsumura et al, 2014) by providing empirical evidence about the differences in the market valuation of emissions under a mandatory reporting regime. The findings can also be useful for capital market participants because they corroborate the notion that mandatory disclosures reduce shareholders' perceptions of environmental risks related to GHG emissions. Finally, the results may be of interest to public and capital market authorities that have already introduced or plan to introduce some form of mandatory reporting of GHG emissions.

The remainder of this study is structured as follows. The next section discusses the previous studies and develops the three hypotheses of the study; the third section describes the empirical model and the sample selection process; the fourth section presents the univariate, multivariate and additional analyses; the final section discusses the findings and draws conclusions.

\section{Background and hypotheses development}

In recent years, carbon emissions have attracted much attention due to the vivid debate around the anthropogenically induced global climate change and the potential policies to cope with this complex but urgent issue. Policies have been introduced at both national and international levels, with some of them attempting to translate an ecological issue into an economic phenomenon (Bebbington \& Larrinaga-Gonzalez, 2008). For instance, the Stern Review on the Economics of Climate Change identifies disastrous impacts on the economy:

"Using the results from formal economic models, the Review estimates that if we don't act, the overall costs and risks of climate change will be equivalent to losing at least 5\% of global GDP each year, now and forever. If a wider range of risks and impacts is taken into account, the estimates of damage could rise to 20\% of GDP or more" (Stern, 2007, p. XV). 
Capital markets have shown an increasing interest in the consequences of climate change in general and carbon emissions specifically (Kauffmann et al, 2012). For instance, Kolk et al (2008) identify investors as a key factor in the development of carbon accounting and reporting. Additionally, institutional investors require companies to provide them with information about climate-change-related risks and opportunities (Solomon et al, 2011), and Ascui (2014) identify that investors' interest is expanding into new areas of carbon accounting, such as forest carbon accounting.

Capital markets' interest in the consequences of climate change has driven a number of scholars to examine the market valuation implications of firms' environmentally related activities. The focus of a number of previous studies has been the relation between firms' market valuation and their level of pollution, such as water pollution (Cormier and Magnan, 1997), sulfur dioxide emissions (Hughes, 2000), toxic releases (Clarkson et al, 2004) and GHG emissions (Chapple et al, 2013; Clarkson et al, 2015; Matsumura et al, 2014). Using a research design similar to this study, these studies find a significant negative association between firms' market valuation and levels of pollution. Specifically, Cormier and Magnan (1997) find that a firm's level of water pollution is negatively associated with its market value, Hughes (2000) shows that sulfur dioxide emissions are negatively associated with firms' market valuation, and Clarkson et al (2004) find that firms with high levels of toxic releases suffer a larger penalty in terms of their market capitalization than firms with low levels of releases.

Regarding GHG emissions, Chapple et al (2013) use a weighted aggregation of emissions of various land, water and air pollutants of a sample of firms listed on the Australian Securities Exchange as a proxy for pollution performance. They find a negative relation between firm values and their levels of aggregated emissions. More importantly for this study, they find that GHG emissions (as reported voluntarily by their sample firms) are negatively associated with firms' market valuation. Similarly, Matsumura et al (2014) find a negative association between voluntarily reported carbon emissions and firm value in a sample of firms listed on the S\&P 500. In addition, they find that firms that decide to not disclose their emissions bear an even higher penalty in terms of their market valuation. Finally, in a European context, Clarkson et al (2015) find a significant negative association between GHG emissions and the market value of firms in the European Union Emissions Trading Scheme. In summary, all previous studies unanimously conclude that GHG emissions are negatively associated with market value. Hence, even though the UK context has not been previously examined, it is reasonable to expect that 
market valuation and GHG emissions of firms listed on the LSE are negatively associated. The first hypothesis that this study examines is formulated as follows ${ }^{6}$ :

H1. The greenhouse gas emissions of firms listed on the London Stock Exchange are negatively associated with their market value.

Prior studies attribute the negative association between GHG emissions and market value to the use of GHG emissions by investors as a proxy for assessing firms' unbooked future environmental liabilities (Clarkson et al, 2004; Hughes, 2000; Matsumura et al, 2014). However, it has been suggested that the voluntary nature of carbon disclosures has a negative effect on their perceived quality by capital market participants who may impose an extra penalty when they value environmental liabilities (Bewley, 2005). For instance, Andrew and Cortese (2011) stress that current voluntary carbon emissions reporting neglects important attributes of corporate reporting, such as reliability and understandability, which might have an impact on investors' decision making. Further, Kolk et al (2008) find that, although an increasing number of firms disclose information about their carbon emissions voluntarily, the comprehensibility of these disclosures is questionable, whereas Stanny and Ely (2008) stress that "... investors in US firms cannot count on receiving information on climate change risk through voluntary disclosure" (Stanny and Ely, 2008, p. 347). Similarly, Sullivan and Gouldson (2012) conclude that, under a voluntary GHG emissions reporting approach, it is very difficult for investors to assess a firm's emissions-related risks.

A theoretical justification for the above critique is given by Unerman and O'Dwyer (2007), who draw from Giddens's reflexive modernity concept (as cited in Unerman \& O'Dwyer, 2007) in terms of the interaction among reflexivity, risk and trust. According to Giddens's reflexive modernity, individuals currently rely heavily upon numerous expert systems because it is impossible for any individual to be an expert in all aspects of their lives. By relying on these experts, individuals place trust in experts' actions, although this trust is often given unconsciously. Reflexivity refers to new knowledge gained by individuals that makes them more aware of expert systems in which they are not experts themselves. In case individuals reflexively appropriate new knowledge that raises their perception of risk about a system, some of them may regard this level of risk as unacceptable, and consequently, they may withdraw their trust in this particular system of experts. It should be noted that the perceived level of risk

\footnotetext{
${ }^{6}$ It is worth stressing that the first hypothesis, although it does not make any new contributions to the literature, provides the necessary foundation for testing the two following hypotheses, which examine differences in the market valuation of carbon disclosures before vis-à-vis after the introduction of the 2013 Regulation.
} 
is not necessarily an objective level, but it may be a socially constructed perception of risk. However, " these socially constructed perceptions of risk are just as important and 'real' to many people in determining their experience of risk as objective distributions of risk" (Unerman \& O’Dwyer, 2007, p. 335).

In terms of environmental reporting, firms' environmental activities (reporting included) can be seen as an expert system because only a few stakeholders will be able to evaluate the real impact of these activities (Unerman \& O’Dwyer, 2007). According to Giddens (as cited in Unerman \& O'Dwyer, 2007), stakeholders will largely be ignorant of the actual effects of firms' environmental activities, and their perception of risk will not change as long as there is no reason for them to think otherwise. Unerman and O'Dwyer (2007) argue that, when a negative environmental externality of firms' activities attracts public attention, stakeholders (shareholders included) react reflexively by increasing their socially constructed perception about firms' environmental risk. In turn, this increased perception of risk leads to a reduction of shareholders' trust towards firms' voluntary disclosures and, consequently, to a decline in shareholders' value (Unerman \& O'Dwyer, 2007). In recent years, carbon emissions have come into the spotlight as possibly the main cause of global warming (Kauffmann et al, 2012; Stern, 2007). Hence, following the rationale of Unerman and O'Dwyer (2007), voluntary carbon emissions reporting may have lost its trustworthiness, and consequently, capital market participants may impose an extra valuation penalty when they value GHG emissions.

Mandatory GHG emissions reporting has been suggested as a means for mitigating the above problem (Kolk et al, 2008; Rankin et al, 2011; Sullivan \& Gouldson, 2012). Talking more broadly about environmental reporting, Unerman and O’Dwyer (2007) suggest reporting regulation as a means of reducing shareholders' concerns about firms' environmental risk. Reducing shareholders' risk perception may have favorable impact on shareholders' trust in firms' disclosures and, consequently, on firms' value. In the case of carbon emissions, to the extent that reporting regulation is expected to forestall shareholders' negative reflexive reaction towards firms' carbon disclosures, it is reasonable to expect the negative association between market value and carbon emissions to decline in magnitude after the introduction of a mandatory GHG emissions reporting regulation.

Although there is no empirical evidence on whether investors value GHG emissions differently in a mandatory reporting context (Andrew and Cortese, 2011), some previous studies provide interesting insights into similar questions. Bewley (2005) provides evidence about differences in the market valuation of booked environmental liabilities accruals before vis-à-vis after the introduction of new environmental reporting regulation. Utilizing a sample 
of Canadian and US firms and using a similar design to that of this study, she provides empirical evidence that the valuation coefficient of booked environmental liabilities accrual is negative in both periods, but its magnitude is much lower after the introduction of the regulation. Furthermore, Hughes (2000) employs a similar design to this research design and shows that stringent regulation may lead to a decrease in the magnitude of the negative association between market value and sulfur dioxide emissions of US listed firms due to changes in the economic and technological factors that the regulation introduces. Another explanation for a potential decline in the negative valuation coefficient of emissions is given by Ioannou and Serafeim (2014), who stress that a new disclosure regulation may impose implementation of new initiatives for emissions reductions and other green activities. To the extent that capital markets identify these new initiatives as indeed reducing GHG emissions, it is reasonable to expect that investors will re-estimate the discounted future cash outflows that are derived from GHG emissions downward. Such a re-estimation will lead to a decrease in the negative valuation of emissions. Sullivan (2009) corroborates the position of Ioannou and Serafeim (2014) by showing that firms with significant regulatory exposure focus more on activities that reduce their GHG emissions. Finally, Clarkson et al (2015) argue that the stringency of the reporting regulation will have an impact on investors' assessment of carbon liabilities. Based on the above discussion, the second hypothesis that this study tests is formulated as follows:

H2. The magnitude of the negative association between market value and greenhouse gas emissions of firms listed on the London Stock Exchange has declined after emissions reporting became mandatory on September 30, 2013, under the amendments of the Companies Act 2006 (Strategic Report and Directors' Reports) Regulations 2013.

Finally, Unerman and O'Dwyer (2007) propose that, when a negative environmental externality of a firm's activities attracts public attention, shareholders may increase their socially constructed perception about the environmental risk not only of this specific firm but also of the whole industry to which the firm belongs. Previous studies acknowledge the strong relation between high carbon emissions and specific energy-intensive industries, such as manufacturing, pulp and paper, chemicals and basic metals (Lund, 2007). Hence, if the proposition of Unerman and O'Dwyer (2007) holds, shareholders' perception about carbonrelated risk should be higher for firms from energy-intensive industries. Consequently, the decline in the negative association between market value and GHG emissions of these firms after the introduction of the 2013 Regulation is expected to be larger than that for firms 
belonging to non-energy-intensive industries. Based on the above discussion, the third hypothesis that this study tests is formulated as follows ${ }^{7}$ :

H3. The magnitude of the negative association between market value and greenhouse emissions has declined more among firms that belong to energy-intensive industries than for firms that belong to non-energy-intensive industries after the introduction of the 2013 Regulation.

\section{Research design}

\subsection{Empirical models}

This study examines whether the GHG emissions of firms listed on the LSE are valued by market participants and, if so, whether the market valuation of GHG emissions has declined after the introduction of the 2013 Regulation, which requires all firms listed on the LSE to report their annual GHG emissions in their director's report for financial years ending on or after September 30th 2013 . Following studies such as Baboukardos and Rimmel (2014), Fazzini and Dal Maso (2016) and, Siekkinen (2016), the value relevance of GHG emissions is examined by employing a model that associates a firm's market value of equity (PR) with its book value of equity (BVS) and earnings (EPS). Following the suggestions of Barth and Clinch (2009), the variables are scaled by the number of common shares outstanding six months after the firm's fiscal year-end (Lang et al, 2006) ${ }^{8}$ :

$\mathrm{PR}_{\mathrm{it}}=\alpha_{0}+\alpha_{1} \mathrm{BVS}_{\mathrm{it}}+\alpha_{2} \mathrm{EPS}_{\mathrm{it}}+\varepsilon_{\mathrm{it}}$

The model is further expanded by including the main variable of interest, GHG emissions, which measures the total annual amount of carbon dioxide and carbon dioxide equivalents (in million metric tons) of a firm as it is recorded in the Thomson Reuters ASSET4 database. Additionally, in order to control for differences in the earnings' market valuation of loss-making firms (Joos \& Plesko, 2005), the indicator variable LOSS is included and is allowed to interact with the earnings variable EPS; second, size effects (Berk, 1995) are controlled by using the variable SIZE; third, profitability effects (Lourenço et al, 2012) are taken into account by using the variable ROE; fourth, the variable LEV controls for leverage (Lins, 2003); and fifth, risk is

\footnotetext{
7 The author would like to thank a reviewer for this suggestion.

8 The definitions of all variables and the sources from which the required data are extracted are presented in the Appendix.
} 
proxied, as suggested by Fama and French (1992), by the ratio of the book value to market value of equity (variable BM). Finally, industry (IND) and year (YR) effects are included, and firm time-invariant effects are controlled by clustering standard errors by firm (Petersen, 2009). The final model that examines the first hypothesis is as follows:

$$
\begin{aligned}
& \mathrm{PR}_{\mathrm{it}}=\alpha_{0}+\alpha_{1} \mathrm{BVS}_{\mathrm{it}}+\alpha_{2} \mathrm{EPS}_{\mathrm{it}}+\alpha_{3} \mathrm{GHG}_{\mathrm{it}}+\alpha_{4} \mathrm{LOSS}_{\mathrm{it}}+\alpha_{5}\left(\mathrm{LOSS}_{\mathrm{it}} \times \mathrm{EPS}_{\mathrm{it}}\right)+\alpha_{6} \mathrm{SIZE}_{\mathrm{it}}+\alpha_{7} \mathrm{ROE}_{\mathrm{it}}+ \\
& \alpha_{8} \mathrm{LEV}_{\mathrm{it}}+\alpha_{9} \mathrm{BM}_{\mathrm{it}}+\sum_{\mathrm{j}=1}^{\mathrm{J}=9} \alpha_{10 \mathrm{j}} \mathrm{IND}_{\mathrm{it}}+\sum_{\mathrm{y}=2011}^{\mathrm{y}=2014} \alpha_{11 \mathrm{y}} \mathrm{YR}_{\mathrm{it}}+\varepsilon_{\mathrm{it}}
\end{aligned}
$$

Coefficient $\alpha_{3}$ is of particular interest for the first hypothesis because it estimates the market valuation of GHG emissions. Based on previous studies regarding the value relevance of GHG emissions, the coefficient $\alpha_{3}$ is expected to have a negative sign and be significantly different from zero.

If the second hypothesis holds, then coefficient $\alpha_{3}$ will be found to be significantly greater in the previous period vis-à-vis the period after the 2013 Regulation took effect (that is, September 30, 2013). To empirically test this difference, Model (1) is further augmented with the period dummy variable D, which equals one for the period after the 2013 Regulation took effect (September 30, 2013, to December 31, 2014) and zero for the period before the 2013 Regulation (January 1, 2011, to August 31, 2013). To examine whether the valuation coefficient of GHG emissions differs between the two periods, the interaction term GHGxD is included; hence, the final model is the following:

$$
\begin{aligned}
& \mathrm{PR}_{\mathrm{it}}=\alpha_{0}+\alpha_{1} \mathrm{BVS}_{\mathrm{it}}+\alpha_{2} \mathrm{EPS}_{\mathrm{it}}+\alpha_{3} \mathrm{GHG}_{\mathrm{it}}+\alpha_{4} \mathrm{D}_{\mathrm{it}}+\alpha_{5}\left(\mathrm{GHG}_{\mathrm{it}} \times \mathrm{D}_{\mathrm{it}}\right)+\alpha_{6} \mathrm{LOSS}_{\mathrm{it}}+\alpha_{7}\left(\mathrm{LOSS}_{\mathrm{it}} \times\right. \\
& \left.\mathrm{EPS}_{\mathrm{it}}\right)+\alpha_{8} \mathrm{SIZE}_{\mathrm{it}}+\alpha_{9} \mathrm{ROE}_{\mathrm{it}}+\alpha_{10} \mathrm{LEV}_{\mathrm{it}}+\alpha_{11} \mathrm{BM}_{\mathrm{it}}+\sum_{\mathrm{j}=1}^{\mathrm{J}=9} \alpha_{12 \mathrm{j}} \mathrm{IND}_{\mathrm{it}}+\sum_{\mathrm{y}=2011}^{\mathrm{y}=2014} \alpha_{13 \mathrm{y}} \mathrm{YR}_{\mathrm{it}}+\varepsilon_{\mathrm{it}}
\end{aligned}
$$

If coefficient $\alpha_{3}$ is negative and significantly different from zero and, at the same time, coefficient $\alpha_{5}$ is found to be positive and statistically significant, then the second hypothesis is confirmed, and it can be inferred that capital market participants in the LSE place a less negative value on GHG emissions after the introduction of the 2013 Regulation, which rendered GHG emissions disclosure mandatory.

Finally, in order to test the third hypothesis, Model 2 above is estimated again for firms that belong to energy-intensive and non-energy-intensive industries separately. Based on the nine industries of the Industry Classification Benchmark, as energy-intensive firms are identified as those that belong to the Basic Materials, Industrials, Oil and Gas and Utilities industries,

\footnotetext{
${ }^{9}$ Variables definitions are provided in the Appendix.
} 
whereas non-energy-intensive firms are identified as those that belong to the remaining Consumer Goods, Consumer Services, Health Care, Technology and Telecommunications industries (Lund, 2007). Similar to the second hypothesis, the coefficient of interest in this case is $\alpha_{5}$. If the third hypothesis is confirmed, then coefficient $\alpha_{5}$ should be positive in both estimations of Model 2 (i.e., energy-intensive industries and non-energy-intensive industries separately) but significantly larger when the model is estimated for firms belonging to the energy-intensive industries than for those belonging to the non-energy-intensive industries.

\subsection{Sample selection and data sources}

The sample utilized in this study is drawn from the Thomson Reuters ASSET4 database, ${ }^{10}$ which provides the GHG emissions data used in this study. For the four-year period under examination (2011-2014), the ASSET4 database contains 1,252 firm/year observations of the firms listed on the LSE. From the initial 1,252 observations, 248 observations are excluded because they belong to the financial industry (Clacher et al, 2013; Dahmash et al, 2009), 217 are excluded because no GHG emissions data are found, 21 are withdrawn due to missing or negative book value of equity (Ahmed et al, 2000; Bugeja and Gallery, 2006), eight are eliminated due to missing earnings, and two are eliminated due to missing market value data. Finally, 14 observations are identified by Cook's distance statistic ${ }^{11}$ as highly influential observations and are also excluded. The final sample consists of 742 firm/year observations (Table 1). All data in this study are retrieved from the Thomson Reuters Datastream, Worldscope and ASSET4 databases.

[Insert Table 1 about here]

\section{Findings}

\subsection{Data description and univariate analysis}

Descriptive statistics for the full sample as well as for the two periods separately (that is, the beginning of 2011 to August 31,2013, and September 30, 2013, to the end of 2014) for all variables used in the regression models are presented in Table 2, Panel A. The average firm of the sample has a share price of 8.10 GBP, net assets per share of 3.19 GBP and earnings per share of 0.70 GBP. Furthermore, the values of most variables (with the exceptions of EPS and

\footnotetext{
10 The Thomson Reuters ASSET4 database contains a wide range of environmental, social and governance information for almost 5,000 firms around the world. All information is collected from publicly available sources, and its quality is scrutinized by experienced analysts (Thomson Reuters, 2015).

11 Observations with Cook's distance greater than $4 / n$, where $n$ is the number of observations, are excluded.
} 
ROE) are not significantly different between the two periods. With regard to the main variable of interest, the average firm in the sample emits 2.88 million tons of GHG emissions annually. The level of emissions is substantially lower than that found in previous similar studies. Specifically, Clarkson et al (2015) and Matsumura et al (2014) report 5.25 million and 11.46 million tons, respectively. Such a large difference can be attributed not only to the different settings examined in previous studies (the EU and the US, respectively) but also to the fact that both studies examine the value relevance of GHG emissions in earlier time periods (2006-2009 for the former and 2006-2008 for the latter). Another interesting finding is that the GHG emissions in the two periods are quantitatively similar (2.91 million tons before the 2013 Regulation took effect and 2.85 million tons afterward). This is a favorable finding for the empirical design because it further ensures that the results of the multivariate analysis are not driven by differences in the magnitude of the variable in the two periods. Finally, Table 2, Panel B presents summary statistics for the firms in the energy-intensive and non-energy-intensive industries separately. As expected, the average firm in the energy-intensive subsample emits a significantly larger volume of GHG than the average firm in the non-energy-intensive subsample (4.79 and 0.68 million tons, respectively).

[Insert Table 2 about here]

Finally, Table 3 presents Pearson's correlation coefficients for all variables. Correlation coefficients among the independent variables are much less than 0.80 , which indicates that there is no problem of multicollinearity (Gujarati, 1995). In addition, the variation inflation factors in all regression specifications (untabulated) are much less than 10, which further confirms that the multivariate analysis results do not suffer from multicollinearity problems (Hair et al, 2008).

[Insert Table 3 about here]

\subsection{Multivariate analysis}

Table 4 presents the results of all regression specifications. First a basic model is estimated in which the market value PR is regressed on the two basic accounting variables (BVS and EPS) and all other control variables. The next two columns present the estimated coefficients of Model 1 and Model 2, which test hypotheses one and two, respectively. The final two columns 
present the estimated coefficients of Model 2 for the energy-intensive and the non-energyintensive industries separately.

To begin, as expected, both BVS and EPS are positively and significantly associated with PR. Furthermore, the coefficient of variable EPSxLOSS is negative and statistically significant at the 1\% level, which is consistent with Joos and Plesko (2005), who show that the earnings valuation coefficient of loss-making firms is significantly lower than that of profit-making firms. In addition, similar to Lourenço et al (2012), profitability (as proxied by the variable ROE) is found to be positively associated with PR; similar to Lins (2003), the leverage LEV is found to be negatively related to PR; and finally, similar to Fama and French (1992), risk (as proxied by the variable BM) is negatively associated with PR. It should be indicated that these results are very similar for all five specifications, with the exception of ROE and LEV coefficients of the energy-intensive industries.

Regarding the first hypothesis, estimating Model 1 reveals that the GHG valuation coefficient is negative and statistically significant at the $1 \%$ level. This finding confirms the first hypothesis that GHG emissions are negatively associated with a firm's market value. Model 1 is estimated for the full period under consideration (2011-2014) and hence, it can be postulated that the average firm listed on the LSE is penalized by the market for its GHG emissions, regardless of whether the emissions are reported on a mandatory or voluntary basis. Interestingly, the magnitude of the coefficient $(-0.220)$ is very similar to that found by Matsumura et al (2014) in a US setting.

[Insert Table 4 about here]

The main focus of the study, however, is to examine whether the market valuation of GHG emissions has declined after the introduction of the 2013 Regulation, which requires all firms listed on the LSE to report their GHG emissions for financial years ending on September 30, 2013, or later. To do so, Model 2 is estimated for the full four-year period. The main variable of interest is the interaction term GHGxD, which captures any differences in the magnitude of the GHG coefficient between the periods before and after the 2013 Regulation took effect. The third column on Table 4 presents the results of estimating Model 2. Similar to the results of Model 1, the coefficient $\alpha_{3}$ of the GHG emissions variable is negative (-0.272) and statistically significant at the $1 \%$ level. More interestingly, coefficient $\alpha_{5}$ of the interaction term GHGxD is found to be positive (0.106) and statistically significant at the 5\% level. This finding indicates that the magnitude of the valuation coefficient of GHG emissions for the period after September 30, 
2013, when GHG emissions reporting became mandatory, is 40\% lower than for the period before the mandatory introduction of the 2013 Regulation.

Finally, the last two columns of Table 4 present the estimated coefficients of Model 2 for the energy-intensive and non-energy-intensive subsamples separately. For the energy-intensive firms, similar to the results of Model 2 for the full sample, the coefficient $\alpha_{3}$ of the GHG emissions variable is negative (-0.171) and statistically significant at the $5 \%$ level, and the coefficient $\alpha_{5}$ of the interaction term GHGxD is positive (0.070) and statistically significant at the $10 \%$ level. For the non-energy-intensive firms, however, although the GHG emissions coefficient is negative (-0.555) and significant at the 5\% level, the coefficient of the interaction term GHGxD is not found to be significantly different from zero. These findings indicate that the magnitude of the valuation coefficient of GHG emissions for the period after the introduction of the 2013 Regulation is significantly lower only for the firms that belong to energy-intensive industries.

\subsection{Additional analysis}

In addition to the main analysis discussed previously, another analysis is performed to test the second and third hypotheses. First, the second hypothesis is tested by comparing the market valuation of the GHG emissions in the period before the introduction of the 2013 Regulation to their market valuation in each of the post-adoption years separately (Table 5, Columns 1 and 2); second, the third hypothesis is tested by estimating Model 2 for firms that have a high volume of annual emissions and firms that have a low volume of annual emissions separately (Table 5, Columns 3 and 4). The findings of all additional tests corroborate the results of the main analysis.

\section{[Insert Table 5 about here]}

The first two columns of Table 5 present the results of the additional analysis to test hypothesis 2. Following Clacher et al (2013), the market valuation of the GHG emissions in the period before the introduction of the 2013 Regulation is compared with their market valuation in each of the post-adoption years separately (that is, the 3-month period of September 30, 2013, to December 31, 2013, and the year 2014). Clacher et al (2013) argue that such a peryear comparison of the post-adoption results gives a better understanding of the persistence of the findings throughout time. The results in both cases are very similar to the results of the main analysis, although the statistical significance of the coefficient $\alpha_{5}$ of the interaction term GHGxD is not as strong as in the main analysis. The relatively weaker significance of these 
results can be attributed to the smaller samples employed in these two estimations, which may reduce the power of the statistical tests.

The last two columns of Table 5 refer to the further examination of the third hypothesis, which is based on the notion that firms that belong to energy-intensive industries are regarded as high emitters and, following the rationale of Unerman and O'Dwyer (2007), these firms are more likely to be penalized by the market under a voluntary GHG emissions reporting regime. If this indeed is the case, then the introduction of a reporting regulation will be more beneficial to these high-polluting firms. The main analysis confirms the third hypothesis of this study by providing evidence of a decline in the negative association between market value and carbon emissions of firms belonging to energy-intensive industries after the introduction of the 2013 Regulation.

Nevertheless, in the main analysis, the categorization of a firm as a high or low emitter is conducted based on the industry to which the firm belongs without considering the actual volume of a firm's emissions. In this additional analysis, instead of categorizing firms as high or low emitters based on their industry, the categorization is based upon the actual volume of GHG a firm emits in a year. Hence, the full sample is divided into high and low emitters based on whether a firm's annual GHG emissions are larger or equal to the sample's median GHG emissions (that is, 0.13 million metric tons). Firms with annual GHG emissions above the median are categorized as high emitters and firms with annual GHG emissions below the median are categorized as low emitters. The results of the analysis confirm the main analysis. The estimation of Model 2 for the high emitters subgroup is similar to previous test results, whereas the estimation of Model 2 for the low emitters subgroup provides evidence that not only the interaction effect (coefficient $\alpha_{5}$ of variable GHGxD) but also the main effect (coefficient $\alpha_{3}$ of variable GHG) are not statistically significant. Hence, to the extent that the volume of annual GHG emissions drives public attention to a firm's environmental risks, this finding can be seen to support the proposition of Unerman and O'Dwyer (2007) that shareholders' perception of a firm's environmental risk increases only when its negative environmental externalities attract public attention.

\section{Discussion and concluding remarks}

This study first examines the market valuation of GHG emissions of firms listed on the LSE. Similar to previous studies (Chapple et al, 2013; Clarkson et al, 2015; Matsumura et al, 2014), the findings indicate a strong negative association between firms' annual carbon emissions and their market value. Following the rationale of previous studies, it is suggested that this negative 
association indicates that GHG emissions are used by investors as a proxy for assessing firms' unbooked future environmental liabilities (Hughes, 2000; Clarkson et al, 2004; Matsumura et al, 2014).

Nevertheless, the voluntary character of these disclosures in most jurisdictions around the world has been suggested to have a negative effect on their perceived quality by capital market participants (Andrew \& Cortese, 2011; Kolk et al, 2008; Stanny \& Ely, 2008; Sullivan \& Gouldson, 2012), who may impose an extra penalty when they value environmental liabilities (Bewley, 2005). This study adopts the theoretical justification of Unerman and O'Dwyer (2007), who draw from Giddens's reflexive modernity concept (as cited in Unerman \& O’Dwyer, 2007) in terms of the interaction among reflexivity, risk and trust and hypothesizes that the introduction of GHG emissions reporting regulations can enhance the trustworthiness of the reporting and, hence, reduce the penalty imposed by investors when valuing GHG emissions. The benefits of mandatory environmental reporting have been acknowledged by both scholars and practitioners (Kolk et al, 2008; de Villiers and van Staden, 2011; Rankin et al, 2011; DEFRA, 2012; Sullivan and Gouldson, 2012; Paddison, 2013; Tauringana and Chithambo, 2015). Nevertheless, whether investors value non-financial environmental information and specifically GHG emissions differently in a mandatory reporting context than in a voluntary reporting regime is an open empirical question (Andrew and Cortese, 2011).

This study takes advantage of the recent amendments of the UK Companies Act 2006 (Strategic Report and Directors' Reports) Regulations 2013, which requires all firms listed on the LSE to report their annual GHG emissions in their director's report for financial years ending on or after September 30,2013, and shows that although the association between market value and carbon emissions has remained significant and negative after the introduction of the 2013 Regulation, the magnitude of the association is significantly smaller.

Following Andrew and Cortese (2011), Bewley (2005) and, Unerman and O’Dwyer (2007), this study suggests that the decrease in the magnitude of the negative association between carbon emissions and market value can be attributed to investors considering mandatory GHG emissions reporting as a means of enhancing their reliability. The fact that a decline in the magnitude is manifested only in firms that belong to energy-intensive industries can be seen as corroborating the proposition of Unerman and O'Dwyer (2007) that when a negative environmental externality of a firm's activities attracts public attention, shareholders may increase their perception not only about the environmental risk of this specific firm but also of the whole industry to which the firm belongs. 
Alternatively, the findings of the study may suggest that the introduction of the 2013 Regulation is observed by investors as a strong signal of future emissions reductions. The decline in the valuation coefficient of GHG emissions indicates that for any given amount of GHG emissions, investors expect less negative future cash flows after the introduction of the 2013 Regulation than before. The reasons for this result may be changes in the economic and technological factors due to the regulation (Hughes, 2000) or implementation of new initiatives for emissions reductions and other green activities imposed by the new regulation (Ioannou and Serafeim, 2014).

Furthermore, following Lee et al (2015), it is suggested that the significantly smaller negative valuation coefficient of GHG emissions that is found after the introduction of the 2013 Regulation may indicate that the new reporting regulation requires firms to report more extensively than before. Lee et al (2015) find that the negative relation between carbon disclosures and capital market returns is mitigated by the frequency of disclosures. Future studies can look at this issue more closely by comparing the level and quality of GHG emissions disclosures before and after the introduction of the 2013 Regulation.

Last, it should be stressed that, although the shortcomings of the current GHG emissions reporting approach is well documented (Haslam et al, 2014), this study aims to provide empirical evidence on the role of GHG emissions reporting under a mandatory reporting regime without, however, challenging the current measurement and reporting framework. Future research can address this issue by examining whether there is a difference in the market valuation of GHG emissions when reported under different reporting frameworks. For instance, does the newly released International Integrated Reporting Framework (IIRC, 2013) provide a more adequate framework for reporting GHG emissions?

In summary, after the introduction of the 2013 Regulation, which requires firms listed on the LSE to include carbon emissions data for their entire organization in their annual reports, a significant decline in the magnitude of the negative association between firms' level of GHG emissions and market valuation is found. The results are potentially of interest to the academic debate on the market valuation implications of GHG emissions, to capital market participants and to public and capital market authorities.

\section{Acknowledgments}

I am thankful to Gunnar Rimmel and Ioannis Tsalavoutas for their valuable comments on earlier versions of the study. Further, I am appreciative of the efforts of Glen Lehman (Editor) and two anonymous reviewers, whose comments improved this study. I am also grateful to the 
Handelsbanken's 'Jan Wallanders och Tom Hedelius' Research Foundation for its generous financial support.

\section{References}

Ahmed, A. S., Morton, R. M., \& Schaefer, T. F. (2000). Accounting conservatism and the valuation of accounting numbers: Evidence on the Feltham-Ohlson (1996) model. Journal of Accounting, Auditing \& Finance, 15(3), 271-292.

Andrew, J., \& Cortese, C. (2011). Accounting for climate change and the self-regulation of carbon disclosures. Accounting Forum, 35(3), 130-138.

Ascui, F. (2014). A review of carbon accounting in the social and environmental accounting literature: what can it contribute to the debate?. Social and Environmental Accountability Journal, 34(1), 6-28.

Baboukardos, D., \& Rimmel, G. (2014) Goodwill under IFRS: Relevance and disclosures in an unfavorable environment. Accounting Forum. 38(1), 1-17.

Barth, M. E., \& Clinch, G. (2009). Scale Effects in Capital Markets-Based Accounting Research. Journal of Business Finance \& Accounting, 36(3-4), 253-288.

Bebbington, J., \& Larrinaga-Gonzalez, C. (2008). Carbon trading: accounting and reporting issues. European Accounting Review, 17(4), 697-717.

Berk, J. B. (1995). A critique of size-related anomalies. Review of Financial Studies, 8(2), $275-286$.

Bewley, K. (2005). The impact of financial reporting regulation on the market valuation of reported environmental liabilities: preliminary evidence from US and Canadian public companies. Journal of International Financial Management \& Accounting, 16(1), 1-48.

Bugeja, M., \& Gallery, N. (2006). Is older goodwill value relevant?. Accounting \& Finance, 46(4), 519-535.

Chapple, L., Clarkson, P. M., \& Gold, D. L. (2013). The cost of carbon: Capital market effects of the proposed emission trading scheme (ETS). Abacus, 49(1), 1-33.

Clacher, I., Ricquebourg, A. D., \& Hodgson, A. (2013). The value relevance of direct cash flows under international financial reporting standards. Abacus, 49(3), 367-395.

Clarkson, P. M., Li, Y., Pinnuck, M., \& Richardson, G. D. (2015). The valuation relevance of greenhouse gas emissions under the European Union carbon emissions trading scheme. European Accounting Review, 24(3), 551-580.

Clarkson, P. M., Li, Y., \& Richardson, G. D. (2004). The market valuation of environmental capital expenditures by pulp and paper companies. The Accounting Review, 79(2), 329-353.

Cormier, D., \& Magnan, M. (1997). Investors' assessment of implicit environmental liabilities: An empirical investigation. Journal of Accounting and Public Policy, 16(2), 215-241.

Dahmash, F. N., Durand, R. B., \& Watson, J. (2009). The value relevance and reliability of reported goodwill and identifiable intangible assets. The British Accounting Review, 41(2), 120-137.

de Aguiar, T. R. S., \& Bebbington, J. (2014). Disclosure on climate change: Analysing the UK ETS effects. Accounting Forum, 38(4), 227-240.

de Villiers, C., \& van Staden, C. (2011). Shareholder requirements for compulsory environmental information in annual reports and on websites. Australian Accounting Review, 21(4), 317-326.

Department for Environment, Food \& Rural Affairs - DEFRA. (2010). The contribution that reporting of greenhouse gas emissions makes to the UK meeting its climate change objectives. A review of the current evidence. http://webarchive.nationalarchives.gov.uk/20130402151656/http://archive.defra.gov.u 
Department for Environment, Food \& Rural Affairs - DEFRA. (2012). Leading businesses to disclose greenhouse gas emissions. https://www.gov.uk/government/news/leadingbusinesses-to-disclose-greenhouse-gas-emissions Accessed 23.0416

Department for Environment, Food \& Rural Affairs - DEFRA. (2013). Environmental Reporting Guidelines: Including mandatory greenhouse gas emissions reporting guidance. https://www.gov.uk/government/uploads/system/uploads/attachment_data/file/20639 2/pb13944-env-reporting-guidance.pdf Accessed 28.03.16

European Council \& Parliament. (2014). Directive 2014/95/EU on amending Directive 2013/34/EU as regards disclosure of non-financial and diversity information by certain large undertakings and groups [2014] OJ L330 http://eur-lex.europa.eu/legalcontent/EN/TXT/PDF/?uri=CELEX:32014L0095\&from=EN Accessed 24.02.16

Fama, E. F., \& French, K. R. (1992). The cross-section of expected stock returns. The Journal of Finance, 47(2), 427-465.

Fazzini, M., \& Dal Maso, L. (2016). The value relevance of 'assured' environmental disclosure. The Italian experience. Sustainability Accounting, Management and Policy Journal, 7(2), 225-245.

Freedman, M., \& Park, J. D. (2014). Mandated climate change disclosures by firms participating in the regional greenhouse gas initiative. Social and Environmental Accountability Journal, 34(1), 29-44.

Gujarati D. (1995). Basic econometrics. (3rd ed.). New York: McGraw-Hill.

Hair J.F., Black W.C., Babin B.J. \& Anderson R.E. (2008). Multivariate data analysis: A global perspective. (7th ed.). London: Pearson Education.

Haslam, C., Butlin, J., Andersson, T., Malamatenios, J., \& Lehman, G. (2014). Accounting for carbon and reframing disclosure: A business model approach. Accounting Forum, 38(3), 200-211.

Hughes, K. E. (2000). The value relevance of nonfinancial measures of air pollution in the electric utility industry. The Accounting Review, 75(2), 209-228.

International Integrated Reporting Council - IIRC. (2013). The International Integrated Reporting Framework. http://integratedreporting.org/wp-content/uploads/2015/03/1312-08-THE-INTERNATIONAL-IR-FRAMEWORK-2-1.pdf Accessed 23.02.16

Ioannou, I., \& Serafeim, G. (2014). The consequences of mandatory corporate sustainability reporting: evidence from four countries. Harvard Business School research working paper, (11-100). http://papers.ssrn.com/soL3/papers.cfm?abstract_id=1799589 Accessed 19.0316

Joos, P., \& Plesko, A. G. (2005). Valuing loss firms. The Accounting Review, 80(3), 847-870.

Kauffmann, C., Less, C. T., \& Teichmann, D. (2012). Corporate Greenhouse Gas Emission Reporting. OECD working papers on International Investment 2012/01. http://search.oecd.org/investment/internationalinvestmentagreements/WP-2012_1.pdf Accessed 26.0416

Kolk, A., Levy, D., \& Pinkse, J. (2008). Corporate responses in an emerging climate regime: the institutionalization and commensuration of carbon disclosure. European Accounting Review, 17(4), 719-745.

KPMG, Centre for Corporate Governance in Africa, Global Reporting Initiative, and United Nations Environment Programme. (2013). Carrots and sticks: Sustainability reporting policies worldwide - Today's best practice, tomorrow's trends. https://www.globalreporting.org/resourcelibrary/Carrots-and-Sticks.pdf Accessed 24.02.16 
Lang, M., Raedy, J. S., \& Wilson, W. (2006). Earnings management and cross listing: Are reconciled earnings comparable to US earnings?. Journal of Accounting and Economics, 42(1), 255-283.

Lee, S. Y., Park, Y. S., \& Klassen, R. D. (2015). Market responses to firms' voluntary climate change information disclosure and carbon communication. Corporate Social Responsibility and Environmental Management, 22(1), 1-12.

Lins, K. V. (2003). Equity ownership and firm value in emerging markets. Journal of Financial and Quantitative Analysis, 38(1), 159-184.

Lourenço, I. C., Branco, M. C., Curto, J. D., \& Eugénio, T. (2012). How does the market value corporate sustainability performance?. Journal of Business Ethics, 108(4), 417-428.

Lund, P. (2007). Impacts of EU carbon emission trade directive on energy-intensive industries-Indicative micro-economic analyses. Ecological Economics, 63(4), 799-806.

Matsumura, E. M., Prakash, R., \& Vera-Muñoz, S. C. (2014). Firm-value effects of carbon emissions and carbon disclosures. The Accounting Review, 89(2), 695-724.

Paddison, L. (2013). Mandatory carbon reporting: can it address climate change? The Guardian, July 19. http://www.theguardian.com/sustainable-business/blog/mandatory-carbonreporting-climate-change Accessed 28.03.16

Petersen, M. A. (2009). Estimating standard errors in finance panel data sets: Comparing approaches. Review of Financial Studies, 22(1), 435-480.

Rankin, M., Windsor, C., \& Wahyuni, D. (2011). An investigation of voluntary corporate greenhouse gas emissions reporting in a market governance system: Australian evidence. Accounting, Auditing \& Accountability Journal, 24(8), 1037-1070.

Siekkinen, J. (2016). Value relevance of fair values in different investor protection environments. Accounting Forum, 40(1)), 1-15.

Solomon, J. F., Solomon, A., Norton, S. D., \& Joseph, N. L. (2011). Private climate change reporting: an emerging discourse of risk and opportunity?. Accounting, Auditing \& Accountability Journal, 24(8), 1119-1148.

Stanny, E., \& Ely, K. (2008). Corporate environmental disclosures about the effects of climate change. Corporate Social Responsibility and Environmental Management, 15(6), 338-348.

Stern, N. H. (2007). The economics of climate change: the Stern review. Cambridge University press.

Sullivan, R. (2009). The management of greenhouse gas emissions in large European companies. Corporate Social Responsibility and Environmental Management, 16(6), 301309.

Sullivan, R., \& Gouldson, A. (2012). Does voluntary carbon reporting meet investors' needs?. Journal of Cleaner Production, 36, 60-67.

Tauringana, V., \& Chithambo, L. (2015). The effect of DEFRA guidance on greenhouse gas disclosure. The British Accounting Review, 47(4), 425-444.

Thomson Reuters. (2015). Thomson Reuters ESG data. ESG data to act on http://financial.thomsonreuters.com/content/dam/openweb/documents/pdf/financial/ asset4-esg-data-fact-sheet.pdf Accessed 24.02.16

Unerman, J., \& O'Dwyer, B. (2007). The business case for regulation of corporate social responsibility and accountability. Accounting Forum, 31(4), 332-353. 
Table 1. Sample selection process

\begin{tabular}{lr}
\hline & Firm/Year obs. \\
\hline Initial number of observations found in ASSET4 database for the period 2011-2014 & 1,252 \\
less observations from Financials industry & 248 \\
less observations with no available GHG emissions data & 217 \\
less observations with missing or negative book value of equity & 21 \\
less observations with missing earnings data & 8 \\
less observations with missing market value data & 2 \\
less highly influential observations identified by Cook's distance ${ }^{\dagger}$ statistic & 14 \\
\hline Final sample & $\mathbf{7 4 2}$ \\
\hline
\end{tabular}

tObservations with Cook's distance higher than $4 / \mathrm{n}$, where $n$ is the number of observations

Table 2. Descriptive statistics

Panel A Descriptives for $\mathrm{H} 1$ \& $\mathrm{H} 2$

\begin{tabular}{|c|c|c|c|c|c|c|c|c|c|}
\hline & \multicolumn{3}{|c|}{ Full sample } & \multicolumn{3}{|c|}{$\begin{array}{c}\text { Before Regulation } \\
(01.01 .2011-08.31 .2013)\end{array}$} & \multicolumn{3}{|c|}{$\begin{array}{c}\text { After Regulation } \\
(09.30 .2013-12.31 .2014)\end{array}$} \\
\hline & Mean & Median & S.D. & Mean & Median & S.D. & Mean & Median & S.D. \\
\hline & \multicolumn{3}{|c|}{$(\mathrm{N}=742)$} & \multicolumn{3}{|c|}{$(\mathrm{N}=403)$} & \multicolumn{3}{|c|}{$(\mathrm{N}=339)$} \\
\hline \multicolumn{10}{|c|}{ Main variables } \\
\hline $\mathrm{PR}$ & 8.10 & 5.21 & 8.14 & 8.04 & 5.14 & 8.17 & 8.17 & 5.35 & 8.12 \\
\hline BVS & 3.19 & 2.01 & 3.76 & 3.29 & 2.06 & 3.69 & 3.06 & 1.90 & 3.83 \\
\hline EPS & 0.70 & 0.43 & 1.03 & 0.81 & $0.49 *$ & 1.10 & 0.58 & $0.37^{*}$ & 0.94 \\
\hline GHG & 2.88 & 0.13 & 10.06 & 2.91 & 0.14 & 9.96 & 2.85 & 0.13 & 10.19 \\
\hline \multicolumn{10}{|c|}{ Controls } \\
\hline SIZE & 14.65 & 14.5 & 1.53 & 14.76 & 14.56 & 1.51 & 14.53 & 14.39 & 1.55 \\
\hline ROE & 0.43 & 0.23 & 2.11 & 0.38 & $0.25^{*}$ & 0.69 & 0.48 & $0.20 *$ & 3.03 \\
\hline LEV & 2.75 & 1.39 & 7.18 & 2.67 & 1.48 & 5.30 & 2.84 & 1.34 & 8.93 \\
\hline BM & 0.60 & 0.39 & 0.75 & 0.62 & 0.41 & 0.81 & 0.56 & 0.37 & 0.66 \\
\hline LOSS & 0.08 & 0.00 & 0.28 & 0.06 & 0.00 & 0.24 & 0.11 & 0.00 & 0.32 \\
\hline
\end{tabular}


Panel B Descriptives for $\mathrm{H3}$

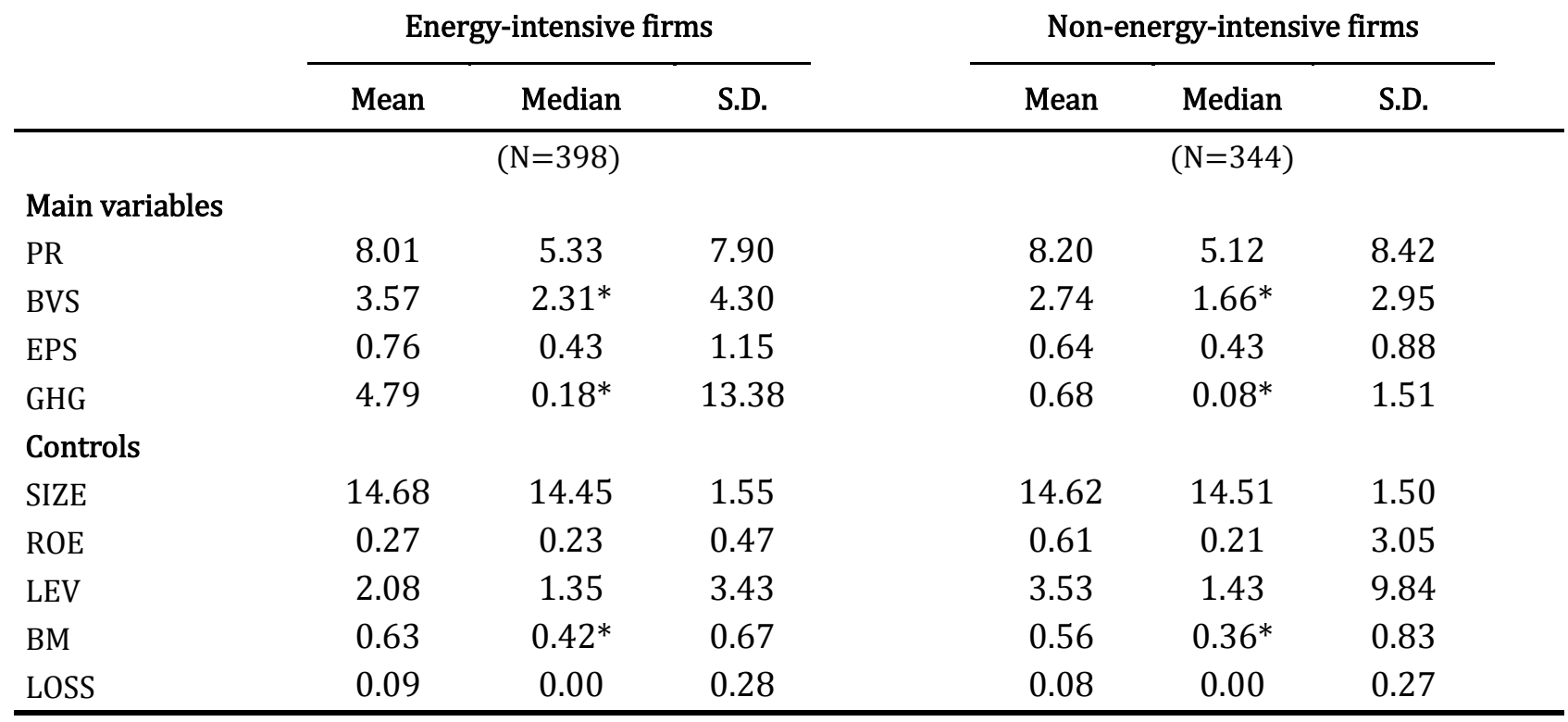

Variables definitions are provided in Appendix

\section{Panel A.}

Asterisk "*" indicates statistically significant difference between the pre- and post- adoption period at least at $5 \%$ level - Wilcoxon test for median difference is applied

Panel B.

Energy-intensive: Firms that belong to Basic Materials, Industrials, Oil and Gas and Utilities industries Non-energy intensive: Firms that belong to Consumer Goods, Consumer Services, Health Care, Technology and Telecommunications industries

Asterisk “*” indicates statistically significant difference between the energy-intensive and the non-energyintensive firms at least at $5 \%$ level - Wilcoxon test for median difference is applied

Table 3. Pearson's correlations coefficients - Full sample

\begin{tabular}{lcccccccc}
\hline & PR & BVS & EPS & GHG & SIZE & ROE & LEV & BM \\
\hline N $=742$ & & & & & & & & \\
BVS & $0.494^{*}$ & & & & & & & \\
EPS & $0.617^{*}$ & $0.622^{*}$ & & & & & & \\
GHG & 0.030 & $0.446^{*}$ & $0.353^{*}$ & & & & & \\
SIZE & $0.242^{*}$ & $0.493^{*}$ & $0.385^{*}$ & $0.521^{*}$ & & & & \\
ROE & $0.135^{*}$ & $-0.084^{*}$ & $0.088^{*}$ & -0.029 & $-0.147^{*}$ & & & \\
LEV & -0.020 & $-0.134^{*}$ & 0.023 & -0.027 & -0.044 & $0.412^{*}$ & & \\
BM & $-0.269^{*}$ & $0.313^{*}$ & $-0.075^{*}$ & $0.222^{*}$ & $0.136^{*}$ & $-0.118^{*}$ & $-0.125^{*}$ & \\
LOSS & $-0.192^{*}$ & -0.059 & $-0.354^{*}$ & 0.037 & -0.019 & $-0.100^{*}$ & 0.001 & $0.297^{*}$ \\
\hline
\end{tabular}

* indicates significant correlation at least at $5 \%$ level

Variables definitions are provided in Appendix 
Table 4. Regressions results

\begin{tabular}{|c|c|c|c|c|c|}
\hline \multicolumn{6}{|c|}{$\begin{array}{l}\text { Model for H1 } \text { PR }_{i t}=\alpha_{0}+\alpha_{1} \text { BVS }_{\text {it }}+\alpha_{2} \mathrm{EPS}_{\text {it }}+\alpha_{3} \mathrm{GHG}_{\mathrm{it}}+\alpha_{4} \mathrm{LOSS}_{\mathrm{it}}+\alpha_{5}\left(\mathrm{LOSS}_{\mathrm{it}} \times \mathrm{EPS}_{\mathrm{it}}\right)+\alpha_{6} \mathrm{SIZE}_{\mathrm{it}}+ \\
\alpha_{7} \mathrm{ROE}_{\mathrm{it}}+\alpha_{8} \mathrm{LEV}_{\mathrm{it}}+\alpha_{9} \mathrm{BM}_{\mathrm{it}}+\sum_{\mathrm{j}=1}^{\mathrm{J}=9} \alpha_{10 \mathrm{j}} \mathrm{IND}_{\mathrm{it}}+\sum_{\mathrm{y}=2014}^{\mathrm{y}=2014} \alpha_{11 \mathrm{y}} \mathrm{YR}_{\mathrm{it}}+\varepsilon_{\mathrm{it}}\end{array}$} \\
\hline & & & & \multicolumn{2}{|c|}{ H3 } \\
\hline Variables & Basic model & $\mathrm{H} 1$ & $\mathrm{H} 2$ & $\begin{array}{l}\text { Energy- } \\
\text { intensive }\end{array}$ & $\begin{array}{c}\text { Non-energy } \\
\text { intensive }\end{array}$ \\
\hline Constant & $\begin{array}{c}7.005^{*} \\
(3.743)\end{array}$ & $\begin{array}{c}-0.709 \\
(3.405)\end{array}$ & $\begin{array}{c}-0.598 \\
(3.534)\end{array}$ & $\begin{array}{l}13.175^{* *} \\
(6.267)\end{array}$ & $\begin{array}{l}-1.087 \\
(4.186)\end{array}$ \\
\hline BVS & $\begin{array}{c}0.705^{* * *} \\
(0.269)\end{array}$ & $\begin{array}{c}0.761^{* * *} \\
(0.274)\end{array}$ & $\begin{array}{c}0.747^{* * *} \\
(0.273)\end{array}$ & $\begin{array}{l}1.106^{* * *} \\
(0.299)\end{array}$ & $\begin{array}{l}0.478^{* *} \\
(0.225)\end{array}$ \\
\hline EPS & $\begin{array}{l}3.646^{* * *} \\
(1.347)\end{array}$ & $\begin{array}{l}3.985^{* * *} \\
(1.194)\end{array}$ & $\begin{array}{l}4.132^{* * *} \\
(1.186)\end{array}$ & $\begin{array}{l}2.140^{*} \\
(1.155)\end{array}$ & $\begin{array}{l}7.358^{* * *} \\
(1.343)\end{array}$ \\
\hline GHG & & $\begin{array}{l}-0.220^{* * *} \\
(0.074)\end{array}$ & $\begin{array}{l}-0.272^{* * *} \\
(0.093)\end{array}$ & $\begin{array}{c}-0.171^{* *} \\
(0.080)\end{array}$ & $\begin{array}{c}-0.555^{* *} \\
(0.266)\end{array}$ \\
\hline $\mathrm{D}$ & & & $\begin{array}{l}-0.058 \\
(0.766)\end{array}$ & $\begin{array}{l}-0.838 \\
(1.110)\end{array}$ & $\begin{array}{c}0.466 \\
(0.878)\end{array}$ \\
\hline GHGxD & & & $\begin{array}{l}0.106^{* *} \\
(0.049)\end{array}$ & $\begin{array}{l}0.070^{*} \\
(0.038)\end{array}$ & $\begin{array}{c}0.275 \\
(0.306)\end{array}$ \\
\hline $\begin{array}{l}\text { Controls } \\
\text { LOSS }\end{array}$ & $\begin{array}{c}1.093 \\
(0.678)\end{array}$ & $\begin{array}{l}1.230 * \\
(0.680)\end{array}$ & $\begin{array}{l}1.252^{*} \\
(0.679)\end{array}$ & $\begin{array}{c}1.350 \\
(1.055)\end{array}$ & $\begin{array}{l}2.265^{* *} \\
(0.993)\end{array}$ \\
\hline LOSSXEPS & $\begin{array}{c}-5.394^{* * *} \\
(1.461)\end{array}$ & $\begin{array}{c}-5.710^{* * *} \\
(1.336)\end{array}$ & $\begin{array}{c}-5.988^{* * *} \\
(1.345)\end{array}$ & $\begin{array}{l}-4.049^{*} \\
(2.087)\end{array}$ & $\begin{array}{c}-8.140^{* * *} \\
(1.381)\end{array}$ \\
\hline SIZE & $\begin{array}{l}-0.173 \\
(0.282)\end{array}$ & $\begin{array}{c}0.378 \\
(0.258)\end{array}$ & $\begin{array}{c}0.365 \\
(0.256)\end{array}$ & $\begin{array}{l}-0.275 \\
(0.374)\end{array}$ & $\begin{array}{c}0.280 \\
(0.298)\end{array}$ \\
\hline ROE & $\begin{array}{c}0.513^{* * *} \\
(0.060)\end{array}$ & $\begin{array}{c}0.559 * * * \\
(0.059)\end{array}$ & $\begin{array}{c}0.557^{* * *} \\
(0.058)\end{array}$ & $\begin{array}{c}0.674 \\
(1.566)\end{array}$ & $\begin{array}{c}0.472^{* * *} \\
(0.052)\end{array}$ \\
\hline LEV & $\begin{array}{c}-0.105^{* * *} \\
(0.027)\end{array}$ & $\begin{array}{c}-0.100^{* * *} \\
(0.027)\end{array}$ & $\begin{array}{c}-0.102^{* * *} \\
(0.027)\end{array}$ & $\begin{array}{l}-0.175 \\
(0.196)\end{array}$ & $\begin{array}{c}-0.090^{* * *} \\
(0.024)\end{array}$ \\
\hline $\mathrm{BM}$ & $\begin{array}{c}-3.856^{* * *} \\
(0.972)\end{array}$ & $\begin{array}{c}-3.627^{* * *} \\
(0.901)\end{array}$ & $\begin{array}{c}-3.637^{* * *} \\
(0.903)\end{array}$ & $\begin{array}{c}-5.778^{* * *} \\
(1.638)\end{array}$ & $\begin{array}{c}-1.830^{* * *} \\
(0.660)\end{array}$ \\
\hline $\begin{array}{l}\text { Industry effects } \\
\text { Year effects }\end{array}$ & $\begin{array}{l}\text { yes } \\
\text { yes }\end{array}$ & $\begin{array}{l}\text { yes } \\
\text { yes }\end{array}$ & $\begin{array}{l}\text { yes } \\
\text { yes }\end{array}$ & $\begin{array}{l}\text { yes } \\
\text { Yes }\end{array}$ & $\begin{array}{l}\text { yes } \\
\text { yes }\end{array}$ \\
\hline $\begin{array}{l}\mathrm{N} \text { (firm/year) } \\
\text { Adj. } \mathrm{R}^{2}\end{array}$ & $\begin{array}{c}742 \\
0.565\end{array}$ & $\begin{array}{c}742 \\
0.608\end{array}$ & $\begin{array}{c}742 \\
0.611\end{array}$ & $\begin{array}{c}398 \\
0.572\end{array}$ & $\begin{array}{c}344 \\
0.752\end{array}$ \\
\hline
\end{tabular}

Energy-intensive: Firms that belong to Basic Materials, Industrials, Oil and Gas and Utilities industries

Non-energy intensive: Firms that belong to Consumer Goods, Consumer Services, Health Care, Technology and Telecommunications industries

$* * *, * *$ and $*$ denote statistical significance at $1 \%, 5 \%$ and $10 \%$ level respectively

Robust standard errors (in parentheses) clustered by firm

Variables definitions are provided in Appendix 
Table 5. Regressions results - additional analysis

\begin{tabular}{|c|c|c|c|c|}
\hline \multicolumn{5}{|c|}{ 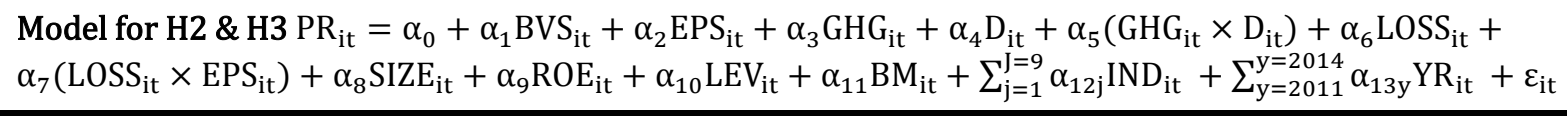 } \\
\hline \multirow{2}{*}{ Variables } & \multicolumn{2}{|c|}{$\mathrm{H} 2$} & \multicolumn{2}{|c|}{ H3 } \\
\hline & pre- vs 2013 & pre- vs 2014 & High emitters & Low emitters \\
\hline Constant & $\begin{array}{c}-3.713 \\
(4.033)\end{array}$ & $\begin{array}{c}0.021 \\
(3.451)\end{array}$ & $\begin{array}{c}5.211 \\
(7.257)\end{array}$ & $\begin{array}{c}1.654 \\
(4.029)\end{array}$ \\
\hline BVS & $\begin{array}{l}0.714^{* *} \\
(0.298)\end{array}$ & $\begin{array}{c}0.974^{* * *} \\
(0.247)\end{array}$ & $\begin{array}{c}0.962^{* * *} \\
(0.296)\end{array}$ & $\begin{array}{c}0.310 \\
(0.210)\end{array}$ \\
\hline EPS & $\begin{array}{l}3.606^{* * *} \\
(1.151)\end{array}$ & $\begin{array}{l}4.183^{* * *} \\
(1.300)\end{array}$ & $\begin{array}{l}2.468^{* *} \\
(1.164)\end{array}$ & $\begin{array}{l}9.621^{* * *} \\
(1.038)\end{array}$ \\
\hline GHG & $\begin{array}{l}-0.260^{* * *} \\
(0.091)\end{array}$ & $\begin{array}{l}-0.320^{* * *} \\
(0.099)\end{array}$ & $\begin{array}{c}-0.223^{* *} \\
(0.086)\end{array}$ & $\begin{array}{c}-6.319 \\
(11.405)\end{array}$ \\
\hline $\mathrm{D}$ & $\begin{array}{c}-0.243 \\
(0.788)\end{array}$ & $\begin{array}{c}0.043 \\
(0.494)\end{array}$ & $\begin{array}{l}-1.438 \\
(1.358)\end{array}$ & $\begin{array}{c}0.181 \\
(0.731)\end{array}$ \\
\hline GHGxD & $\begin{array}{c}0.124^{*} \\
(0.063)\end{array}$ & $\begin{array}{c}0.089^{*} \\
(0.052)\end{array}$ & $\begin{array}{l}0.090^{* *} \\
(0.045)\end{array}$ & $\begin{array}{c}12.457 \\
(11.753)\end{array}$ \\
\hline $\begin{array}{l}\text { Controls } \\
\text { LOSS }\end{array}$ & $\begin{array}{c}1.384 \\
(0.853)\end{array}$ & $\begin{array}{c}0.789 \\
(0.909)\end{array}$ & $\begin{array}{c}3.285^{* * *} \\
(0.976)\end{array}$ & $\begin{array}{l}1.485^{* *} \\
(0.649)\end{array}$ \\
\hline LOSSXEPS & $\begin{array}{l}-6.036^{* * *} \\
(1.209)\end{array}$ & $\begin{array}{l}-7.647^{* * *} \\
(2.558)\end{array}$ & $\begin{array}{l}-5.083^{* *} \\
(2.055)\end{array}$ & $\begin{array}{l}-10.608^{* * *} \\
(1.081)\end{array}$ \\
\hline SIZE & $\begin{array}{l}0.553^{*} \\
(0.293)\end{array}$ & $\begin{array}{c}0.299 \\
(0.253)\end{array}$ & $\begin{array}{c}0.202 \\
(0.482)\end{array}$ & $\begin{array}{c}0.060 \\
(0.292)\end{array}$ \\
\hline ROE & $\begin{array}{l}1.584^{* * *} \\
(0.402)\end{array}$ & $\begin{array}{c}0.540^{* * *} \\
(0.057)\end{array}$ & $\begin{array}{l}3.191^{* *} \\
(1.301)\end{array}$ & $\begin{array}{c}0.426^{* * *} \\
(0.032)\end{array}$ \\
\hline LEV & $\begin{array}{l}-0.133^{* * *} \\
(0.042)\end{array}$ & $\begin{array}{l}-0.106^{* * *} \\
(0.029)\end{array}$ & $\begin{array}{l}-0.181^{* * *} \\
(0.067)\end{array}$ & $\begin{array}{l}-0.123^{* * *} \\
(0.016)\end{array}$ \\
\hline BM & $\begin{array}{l}-3.345^{* * *} \\
(0.925)\end{array}$ & $\begin{array}{l}-3.479^{* * *} \\
(0.762)\end{array}$ & $\begin{array}{l}-4.593^{* * *} \\
(1.222)\end{array}$ & $\begin{array}{l}-1.506^{* * *} \\
(0.539)\end{array}$ \\
\hline $\begin{array}{l}\text { Industry effects } \\
\text { Year effects }\end{array}$ & $\begin{array}{l}\text { yes } \\
\text { yes }\end{array}$ & $\begin{array}{l}\text { yes } \\
\text { yes }\end{array}$ & $\begin{array}{l}\text { yes } \\
\text { yes }\end{array}$ & $\begin{array}{l}\text { yes } \\
\text { yes }\end{array}$ \\
\hline $\begin{array}{l}\mathrm{N} \text { (firm/year) } \\
\text { Adj. } \mathrm{R}^{2}\end{array}$ & $\begin{array}{c}534 \\
0.594\end{array}$ & $\begin{array}{c}611 \\
0.659\end{array}$ & $\begin{array}{c}371 \\
0.612\end{array}$ & $\begin{array}{c}371 \\
0.764\end{array}$ \\
\hline
\end{tabular}

pre- vs 2013: 01.01.2011-08.31.2013 vs 09.30.2013-12.31.2013

pre- vs 2014: 01.01.2011-08.31.2013 vs 01.01.2014-12.31.2014

High emitters: Observations with GHG above the median of the sample (0.13 million metric tons)

Low emitters: Observations with GHG below the median of the sample ( 0.13 million metric tons)

$* * *, * *$ and ${ }^{*}$ denote statistical significance at $1 \%, 5 \%$ and $10 \%$ level respectively

Robust standard errors (in parentheses) clustered by firm

Variables definitions are provided in Appendix 


\section{Appendix}

Variables definitions

\begin{tabular}{|c|c|}
\hline Variables & Description \\
\hline PR & $\begin{array}{l}\text { Market value of equity (Datastream item identifier: MV) six months after fiscal year- } \\
\text { end scaled by the number of common shares (Datastream item identifier: } \\
\text { WC05301) }\end{array}$ \\
\hline BVS & $\begin{array}{l}\text { Book value of equity (Datastream item identifier: WC03995) scaled by the number } \\
\text { of common shares (Datastream item identifier: WC05301) }\end{array}$ \\
\hline EPS & $\begin{array}{l}\text { Earnings before interest and taxation (Datastream item identifier: WC18191) } \\
\text { scaled by the number of common shares (Datastream item identifier: WC05301) }\end{array}$ \\
\hline GHG & $\begin{array}{l}\text { Total greenhouse gas emissions in million metric tons. (ASSET4 identifier: } \\
\text { ENERDP023) }\end{array}$ \\
\hline D & $\begin{array}{l}\text { Binary variable which equals one for the period after the Companies Act } 2006 \\
\text { (Strategic Report and Directors' Reports) Regulations } 2013 \text { took affect (i.e. } \\
09.30 .2013-12.31 .2014 \text { ) and zero for the period before (i.e. 01.01.2011- } \\
08.31 .2013 \text { ) }\end{array}$ \\
\hline LOSS & Binary variable which equals one if EPS is negative and zero otherwise \\
\hline SIZE & Natural logarithm of total assets (Datastream item identifier: WC02999) \\
\hline ROE & $\begin{array}{l}\text { Return on equity computed as earnings before interest and taxation (Datastream } \\
\text { item identifier: WC18191) divided by book value of equity (Datastream item } \\
\text { identifier: WC03995) }\end{array}$ \\
\hline LEV & $\begin{array}{l}\text { Leverage computed as total liabilities (Datastream item identifier: WC03351) } \\
\text { divided by book value of equity (Datastream item identifier: WC03995) }\end{array}$ \\
\hline BM & $\begin{array}{l}\text { Book-to-market ratio computed as book value of equity (Datastream item } \\
\text { identifier: WC03995) to market value of equity (Datastream item identifier: MV) }\end{array}$ \\
\hline IND & $\begin{array}{l}\text { Multiple dummy variable based on the nine out of the ten industries (Financials } \\
\text { industry excluded) of the Industry Classification Benchmark (Datastream item } \\
\text { identifier: ICBIC) }\end{array}$ \\
\hline YR & Multiple dummy variable based on the four years under examination \\
\hline
\end{tabular}

All variables are based on data extracted from Thomson Reuters Datastream, Worldscope and ASSET4 databases 